\title{
Theoretical aspects of innovation management
}

\author{
Dmitry Fedulov1, *, Alexander Pobedin2 \\ ${ }^{1}$ South Ural State University, 76 Lenin Ave, Chelyabinsk, 454080, Russia \\ ${ }^{2}$ Urals Institute of Management - Branch of the Russian Presidential Academy of National Economy and Public Administration, 66, \\ 8 March St., Ekaterinburg, 620066, Russia
}

\begin{abstract}
In recent decades, the need to theorize and practise innovation has become apparent to many domestic and foreign companies. The process of introducing innovation mechanisms differs from company to company. Businesses and innovation theory experts do not yet agree on the methodology for implementing innovation effectively. The increasingly competitive environment of the world encouraged many companies to move towards innovative development. Innovation became an important tool for sustainable development for many companies in an unstable and rapidly changing external environment. Innovation is used to create a new product or develop a process to increase a company's profits and strengthen its market position. The term "innovation" has a different understanding today, depending on the area of application: firms or sectors. The article examines the theoretical concepts of innovation.
\end{abstract}

\section{Introduction}

In the 21st century, the need for innovation has become apparent to many domestic and foreign companies. The processes of globalization and integration of the world economy facilitated an active transition to innovative development in many sectors of the economy. Innovation has become an important tool for progressive development for many companies in an unstable and rapidly changing business environment. Innovation is used to create a new product or develop a process to increase a company's profits and strengthen its market position. The process of introducing innovation mechanisms differs from company to company, but a common motive for introducing innovation into business practices is the increasing competition between companies in an increasingly unstable and volatile external environment. The term "innovation" has a different understanding today, depending on the area of application: firms or sectors. Many researchers believe that innovation should contribute to meeting the public interest and the basic needs of citizens. To ensure the achievement of the desired results, innovative companies need to assess the resources required and the tools needed. The article examines the theoretical concepts of innovation.

\section{Results and discussion}

At the beginning of the 21 st century, the need to theorize and practise innovation has become apparent to many domestic and foreign companies. The process of introducing innovation mechanisms differed from company to company. Businesses and innovation theory experts do not yet agree on the methodology for implementing innovation effectively.

Conway and Steward linked innovation to the practice of successfully introducing a new product or idea into the marketplace to provide a solution to a firm's existing problems [1]. Innovations included new processes, ideas, services and products designed to improve the functioning of the organization's structural units, reduce costs and improve quality overall.

Sakalyte and Bartuseviciene linked innovation firstly to internal development and research based on the company's own knowledge and developments, and secondly to the use of the experience of innovations applied by other companies. Internal development and research enable the application of new methods to the production process, provides access to new markets and enables the efficient application of production processes to busy markets [7].

Many researchers have repeatedly emphasised the paramount importance of innovation [2,4,5,11].

Researchers of innovations define them as an incentive for the development of the economy of countries, society and scientific and technological progress in general.

Let's look at the existing rating of countries by the level of innovation, presented in the figure below [12]

\footnotetext{
*Corresponding author: d373@ rambler.ru
} 


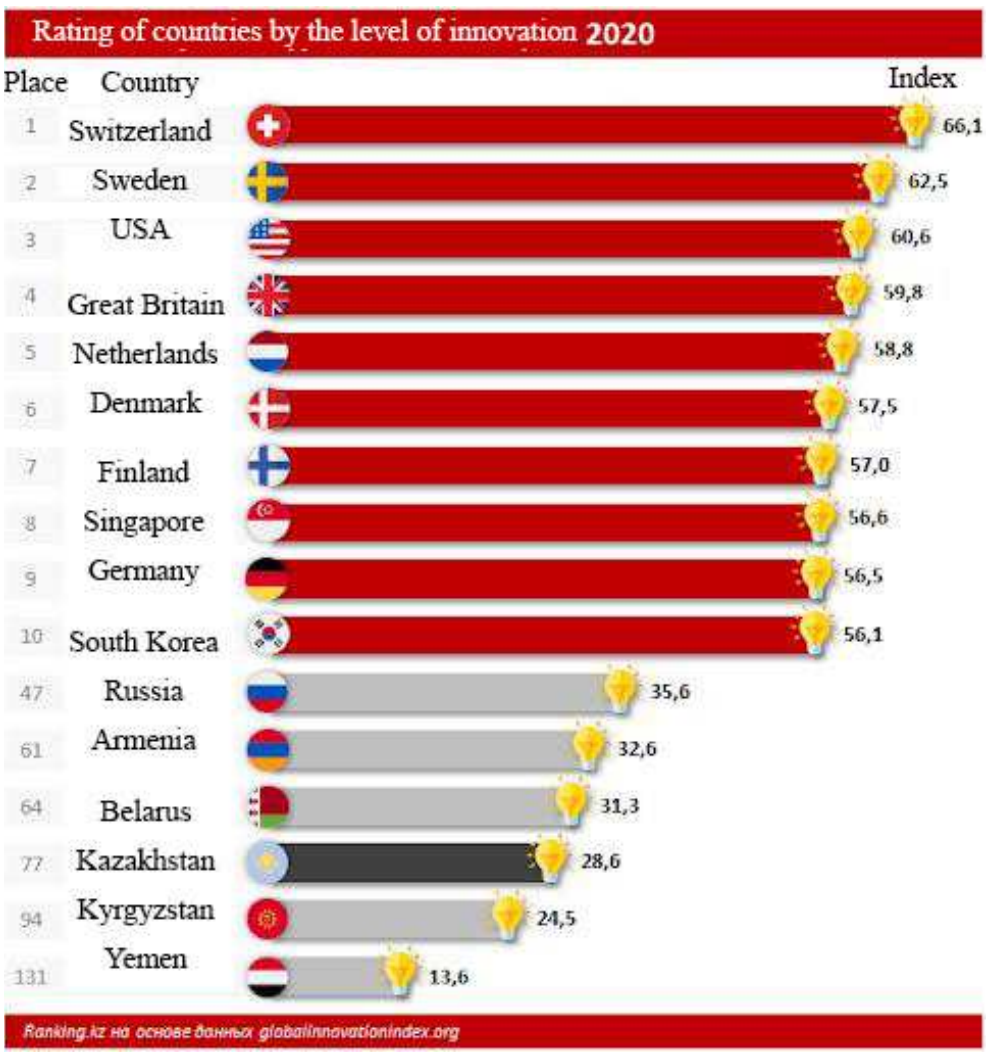

Fig 1. rating of countries by the level of innovation 2020

As we can see, the leading positions in the ranking in terms of innovation implementation are occupied by developed countries of the world. It is in them that special attention is paid to the development of innovations in various areas.

Researchers of modern innovations distinguish the following areas [13]:

- Biotechnology

- Architecture

- Computer technology

- Automotive industry

- Interaction with the surrounding world

- - -Energy

- Medicine

- Scientific potential

- Robots

- Nanowear

Scientific American magazine and experts of the World Economic Forum highlighted the following innovative technologies) [14]:

- Bioplastics from plant waste

- Social robots

- Metalinzy

- A potential cure for Alzheimer's

- Smart fertilizers

- Joint telepresence

- Blockchain against food poisoning

- Safe nuclear reactors

- $\quad$ Storing data in DNA

- Network energy storage devices.

For this reason, innovation activities, combining aspects such as entrepreneurship, creation and learning, are regarded as production activities, providing a shift from the previous one to a new, higher level. This refers to a product, a system or a process. These transformations aim to meet the differentiated needs of society and to ensure a competitive environment with all market actors.

Schumpeter and Drucker understood innovation as an area of entrepreneurial activity focused either on taking advantage of a new technology (process) that was not previously used, or on fundamentally transforming the product using inventions [16].

Love and Roper defined innovation as a process that includes various activities, such as distinguishing a new product, creating, producing it, and executing a marketing strategy[9]. These researchers distinguish the following stages of new product creation: recognition (authentication) of the newly created product, design and packaging of the new product, consultancy services related to product development and promotion of the product in the market. As can be noted, these steps are quite time-consuming and require a fair amount of existing knowledge.

In summary, the process of introducing innovation drives radical change in an organization. Innovation is used to create a new product or develop a process to increase a company's profits and strengthen its market position.

The need for innovation research has now become apparent to many in the scientific community, business and policy makers, as innovation today provides a significant competitive advantage for companies and ensures the growth of economic wealth in society. Researchers around the world today use many models of innovation, based on different approaches. 
Most research scholars use Schumpeter's classical theory of production factors as their base, arguing that market structure and size are the main innovation motives. Subsequently, the more in-depth research into different industries and the specifics of knowledge management found the theory of production factors discussed above to be irrelevant. It is generally accepted that environmental factors such as training and additional knowledge, as well as management techniques, are more important than the specifics of each individual industry. That is why innovation is considered to create new markets, reduce production costs, improve product quality and increase production output. Successful innovation in the production process ensures increased profitability[17].

An important aspect characteristic of the concept of innovative development is the speed of innovation. This can be considered from the following perspectives. First, speed of innovation corresponds to the initiation of the innovation process and the introduction of a newly created product on the market. Innovation is critical in the current volatile and unstable markets, increasing product differentiation and rapidly changing customer preferences. The above-mentioned reasons make it necessary to launch new products faster than competitors [11]. Secondly, the speed of innovation in production relates to the company's ability to adopt new technology as quickly as possible. The greatest benefit from innovation will accrue to the companies that are the first to adopt the innovative mode of production, considering the level of risk involved to be acceptable [11].

According to Hong, innovation activities allow companies to move to a fundamentally new level by significantly improving a product or process, while ensuring an increase in market share and profits [6]. The economic theory considers a situation in which a firm that undertakes a radical innovative transformation of its production process or technology can become a monopolist for some time, maximizing profits and increasing its market share. Arias-Aranda believes that innovation provides a sufficient level of stability for a company over a sufficiently long time and to win in an ever-increasing competitive struggle[1].

Research on contemporary types of innovation highlights the importance of innovation development, which relies on important components of the innovation system such as institutions, buyers and suppliers. This is why it is so important for an innovative company to have proven partners [8]. Other researchers believe that the benefits of a company's innovation activities come from bringing a new product to market quickly. Sometimes it is possible for companies that use an innovation strategy in their operations to create new markets at the expense of the significant advantages arising from it [11].

Considering innovation as a set of actions has become relevant in recent decades. It is important to have a continuous innovation process involving the analysis, creation and introduction of new products and services to the market. This involves approaching innovation as a system, as many actors are involved in the process. Considering this systematic approach, we note that the development of this approach depends on a number of factors: methods for promoting the innovative product or service, the specific technology used in the production process, the interaction between buyers and distributors of innovative products, the specific characteristics of the product, the market environment and other external environment factors.

There is currently no consensus among researchers of modern innovation categories regarding the distinction between process innovation and product innovation, as many academics believe such a division is arbitrary. The distinction between process innovation and product innovation may be relevant if there is a comparative analysis of service and industrial companies. The strongest link between process innovation and product innovation is evident when considering service businesses rather than industrial companies. This is due to the specific functioning of the service sector, which involves an immediate and direct sense of the quality of the service provided by customers [4].

The development of innovative products is paramount to economic growth. This is why it is necessary to study existing publications on the subject to understand the correlation between business profitability and innovation, and to recognize the need to develop a company's innovative directions to ensure stability and sustainability in the future.

The innovative way of development provides the information necessary for the emergence of new technologies. Information and innovative production technologies enable new companies to become market leaders not only at the country level, but also on a global scale, creating groundbreaking products that have never been seen before. Innovative production technologies enable new companies to take a significant share of the market, meeting the special needs of customers by producing rare goods and services.

A close relationship between business and innovation is key to the success of companies. The ability to take risks and innovate in the production process are key ingredients for a successful business. The successful implementation of innovative concepts in the operations of various companies shows that small firms, which are the most flexible and adaptable to implement anything new, have the most success. By innovating, small firms have a significant impact on markets, helping to transform them[15].

The concept of innovative production is based on a creative approach that involves the ability to think in new ways, to see the prospects for change in existing technologies and processes and the new opportunities that are available to companies when they embark on a journey of innovation. The innovative way of development changes the production and management methods and the organizational structure of the company [10]. We note that the innovative way of development ensures that the company achieves a meaningful competitive advantage in the marketplace.

Innovative companies apply tools to improve the production process, achieving a meaningful competitive advantage not only in national markets, but also internationally. Modern information technology is also significantly expanding the horizons of innovative 
companies, enabling the necessary communication between the company and its customers, as well as providing the necessary knowledge about customers and competitors.

The choice of innovative development gives a company a competitive edge through the introduction of new technology, making it possible to produce products with special properties that are not available on the market. The ability to manufacture customized products comes from an innovative approach based on the latest scientific advances. By ensuring the possibility of producing unique products, the company achieves maximum customer loyalty, as the product cannot be bought from other competing companies. The overall value of an innovative company increases relative to its competitors, and it can take a leading position in the international market. But the above-mentioned opportunities are only available to companies that consistently follow an innovative path of development and offer unique products and a high level of service [7].

Innovative development paths are not only important for manufacturing companies, but also individual countries. This is the reason why the concept of innovative development now exists internationally as a key factor in economic growth. There is a view that it is possible to consider the processes of production globalization and internationalization, as well as entry into international markets, as innovation [7].

We should note that any company that chooses an innovative path of development and introduces innovations into the production process should strive to maximize the capitalization of investments in innovation not only in the long term, but also in the medium and short term. A company needs to develop a certain organizational structure to foster innovation. This organizational structure will facilitate the acquisition of necessary information to support innovative development and the development of innovative products and services. These transformations should subsequently lead to a strengthening of the company's market position, margins and market share.

Ganotakis and Love suggest using the Innovation Value Chain (IVC) as a convenient mechanism for indicating the strengths and weaknesses of companies that have embarked on innovation. This tool is suitable for companies operating in the high-tech sector and developing innovative, unparalleled products [5].

By offering unparalleled, innovative products to the market, high-tech companies contribute to the competitiveness of individual industries and the economy as a whole.

When considering the implications of the innovation value chain for a company, we note an increase in overall productivity, a clearer view of bottlenecks, the ability to trace multiple connecting elements throughout the production process and the ability to target financing more effectively as a result of the innovation. As a result, the company has the opportunity to maximize the benefits of innovation once the product or service has been introduced to the market.

\section{Conclusions}

Thus, we have considered the essence of the innovative development path of a company, the impact of innovation on economic growth and the increase in the level of well-being of society as a whole. Innovation is a tool for improving a company's economic efficiency and strengthens its position not only in national but also in global markets. Innovation contributes to scientific and technological progress, the development of society as a whole and global competitiveness. As we have noted in this paper, innovation today is perceived as a rather voluminous concept, so we have looked at existing concepts of innovation. The article presents different theoretical approaches to the creation of innovation.

\section{References}

1. D. Arias-Aranda et al. European Journal of Innovation Management., 4(3) (2001)

2. M. Bogers, J. West Creativity and Innovation Management., 21(1) (2012)

3. S. Conway, F. Steward Managing and shaping innovation. (Oxford University Press, USA, 2009)

4. F. Damanpour, Journal of Management Studies., 46(4) (2009)

5. P. Ganotakis, J. H. Love, Journal of Product Innovation Management, 29(5) (2012)

6. S. Hong, et al. Journal of Economic Surveys., 26(3) (2012)

7. G. A. Knight, S. T. Cavusgil Journal of International Business Studies., 35(2) (2004)

8. K. Laursen, A. Salter Strategic Management Journal., 27 (2006)

9. J. H. Love, S. Roper Industry and Innovation.,16(3) (2009)

10. G. T. Lumpkin, D. Dess, Academy of Management Review 21(1) (1996)

11. Prajogo D. I. Knowledge and Process Management, 13(3) (2006)

12. Global innovation Index. 2020 Retrieved from: https://www.globalinnovationindex.org/gii2020-report\#

13. Agency for Innovation and Development of Economic and Social Projects Retrieved from: http://www.innoros.ru/

14. Ten innovative technologies that will change our lives Retrieved from: https://trends.rbc.ru/trends/innovation/5df26cc19a $\underline{79477250 \mathrm{ac} 8483}$

15. H. K. Steensma, et al. The Academy of Management Journal., 43(5) (2000)

16. O. Stripeikis, J. Ramanauskas, Management theory and studies for rural business and infrastructure development, 1(25) (2011) 
17. E. Webster Economics of Innovation and New Technology, 13(8) (2004) 